\title{
Ovarian Retiform Sertoli-Leydig Cell Tumor
}

National Cancer Institute

\section{Source}

National Cancer Institute. Ovarian Retiform Sertoli-Leydig Cell Tumor. NCI Thesaurus.

Code C39971.

A Sertoli-Leydig cell tumor of the ovary in which anastomosing, slit-like spaces

resembling rete testis constitute at least $90 \%$ of the tumor elements. It may present with

estrogenic and less often androgenic manifestations. It usually follows a benign clinical course. 